\title{
Nu: uma perspectiva despida de dogmatismos
}

\section{Marco Naccarato*}

Resumo: Usando o nu como fio condutor do texto, o artigo aborda o ceticismo em três diferentes momentos da história na tentativa de relacionar esta doutrina a uma abertura para a alteridade em contraponto às posturas dogmáticas.

Palavras-chave: ceticismo, dogmatismo, preconceito, relativismo cultural.

Abstract: Using the nude as the guiding thread of the text, this article approaches skepticism at three different moments in history in an attempt to connect this doctrine to an openness to alterity as opposed to dogmatic attitudes.

Keywords: skepticism, dogmatism, prejudice, cultural relativism.

\begin{abstract}
Pirro de Élida era filho de Pleistarco, segundo narra Diócles. Como disse Apolodoro, nas Crônicas, primeiro foi pintor e escutou [as aulas] de Brisson [ou] de Estilpo e, depois, de Anaxarco, de acordo com Alexandre, nas Sucessões. Tendo acompanhado o último por toda parte, entrou em contato com os gimnosofistas, na Índia, e com os magos [persas].(DIÓGENES LAÉRCIO em "Vidas e doutrinas dos filósofos", IX 61)
\end{abstract}

É sabido que Pirro de Élida acompanhou Alexandre, o Grande, em suas investidas ao oriente, e que durante esse período entrou em contato com gimnosofistas na Índia e magos na Pérsia. Os faquires, chamados gimnosofistas, ( $\gamma v \mu \nu$ ganharam tal alcunha dos gregos por não usarem roupas, com o pretexto de que elas seriam prejudiciais à pureza de pensamento. Tinham hábitos frugais, uma doutrina ascética e viviam conforme a natureza, além de, outrora privilegiados, terem rompido com o sistema social de castas hindu (eram, portanto, ex-brâmanes) e com a tradição religiosa. Às margens do rio Indo, Alexandre encontrou uma dezena deles: 
Ele [Alexandre] capturou dez dos Gimnosofistas que tinham feito de tudo para fazer os Sabbas se revoltarem causando grandes problemas para os macedônios. Estes filósofos tinham a fama de serem inteligentes e concisos ao responderem perguntas, e, portanto, Alexandre fez perguntas bastante difíceis a eles declarando que seria condenado à morte o primeiro que respondesse erroneamente a uma pergunta e assim sucessivamente; em seguida, ordenou a um deles, o mais velho de todos, para ser o juiz no concurso. A primeira pergunta era o que seria mais numeroso, os vivos ou os mortos, ao que um filósofo disse ser os vivos, já que os mortos já não existem mais. A segunda pergunta era o que produzia as maiores bestas, a terra ou os mares, ao que o segundo filósofo disse ser a terra, uma vez que os mares eram parte da terra. A terceira pergunta era qual seria o animal mais astuto, ao que o terceiro filósofo disse: "Aquele que até este momento o homem não descobriu." A quarta pergunta era por que eles induziram os Sabbas a se revoltarem, ao que o quarto filósofo respondeu: "Porque eu queria que eles vivessem nobremente, ou então morressem nobremente". A quinta pergunta era o que era mais velho, o dia ou a noite, ao que o quinto filósofo respondeu: "O dia, por um dia"; e acrescentou sobre o fato de o rei expressar espanto, que as questões difíceis devem ter respostas difíceis. Passando, então, para o sexto filósofo, Alexandre perguntou como um homem poderia ser mais amado; "Se", disse o filósofo, "ele é o mais poderoso e no entanto não inspira medo." Aos três restantes, a um deles foi perguntado como um homem poderia tornar-se um deus, ao que o sétimo filósofo respondeu: "Ao fazer algo que um homem não pode fazer"; aquele que foi perguntado qual era a mais forte, a vida ou a morte respondeu: "A vida, uma vez que ela suporta tantos males." E a última pergunta ao nono filósofo foi quanto tempo um homem deve viver, ao que ele respondeu: "Até que ele não considere a morte como melhor do que a vida." Assim, então, voltando-se para o décimo filósofo e juiz, Alexandre ordenou-lhe dar a sua opinião. O juiz declarou que eles tinham respondido pessimamente, um pior que o outro. "Bem, então", disse Alexandre, "deverás morrer primeiro por dar tal sentença." "Isso não pode ser, ó rei", disse o juiz, "a menos que tu disseste falsamente que condenaria à morte o primeiro deles que respondesse pior. (PLUTARCO em "Vida de Alexandre", CVIII)

Parece possível relacionar a postura de Pirro à sua experiência no Oriente, como aponta o historiador Diógenes Laércio na obra Vidas e doutrinas dos filósofos ilustres. Pirro, ao retornar a Élida, sofreu influência e incorporou hábitos dos faquires, e assim inaugurou seu ceticismo, mas, sobretudo, o impacto com a diferença, com uma nova cultura, subsidiou sua doutrina filosófica, que nega qualquer afirmação dogmática, pois não acredita ser possível

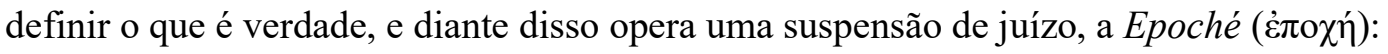

Disto decorre [ser o pirronismo] o mais nobre filosofar: por ter introduzido em seu modo de vida os estados de inapreensibilidade e de suspensão de juízo, como diz Ascânio de Adbera. Sendo assim, nada dizia ser nem belo, nem feio, nem justo, nem injusto, mas, igualmente, sobre todas as coisas, afirmava nada ser em verdade... (DIÓGENES LAÉRCIO em "Vidas e doutrinas dos filósofos ilustres", IX 61)

O ceticismo de Pirro ressurge na Era Moderna com Michel de Montaigne, e, curiosamente, se o primeiro construiu sua filosofia do encontro com homens nus, o segundo se utiliza do encontro com homens nus para propor sua filosofia. Montaigne, sob a mesma 
condição de diferença e choque cultural vivenciada por Pirro ao alcançar o oriente, escreve um ensaio sobre os índios canibais encontrados no Brasil na época do descobrimento, e aborda a diversidade de costumes e experiências humanas exacerbada no encontro do europeu com o nativo americano. Como cético, ao suspender o juízo, relativiza ambas as posições, como formula Danilo Marcondes:

O ceticismo apresenta, de um ponto de vista metodológico, uma forma de tratar essa dificuldade, preparando-nos para o novo ao nos despir dos preconceitos e nos fazer ter a mente aberta diante dele e não apenas de tratá-lo por analogia ou comparação com o antigo. [...] O papel cético de "nettoyer l'esprit" nos prepararia para essa nova atitude, para a abertura do espírito, para o olhar antropológico que, através do recuo, do régardé loigné, é capaz de examinar a experiência humana em sua diversidade. (DANILO MARCONDES em "Montaigne, a descoberta do novo Mundo e o Ceticismo Moderno", p. 431-432)

Como bem apontado por Marcondes, a investigação de Montaigne não se dá em termos de oposição com a alteridade, mas de mostrar, nas diferenças de costumes entre os povos, a pluralidade da experiência humana.

Partindo desse ponto, o ceticismo pode nos dar essa possibilidade de despir-se, de ficarmos perplexos e instigados com a descoberta do novo, do diferente, que nos força a suspender o juízo sob a condição de compreender o outro (E não é essa a postura original da Filosofia, a saber, o espanto?). Em contraponto, ao partirmos de uma visão de mundo dada previamente, projetamos nosso ideal sobre o outro, e construímos nossa relação com a alteridade como uma oposição. Digamos que seja esta a postura dogmática, pois parte de uma verdade anterior, de costumes incorporados ou mesmo de preconceitos.

A postura do conquistador europeu na descoberta do Novo Mundo, a de reduzir o outro ao não eu, e logo, de imposição cultural sobre o índio, parte de uma visão de mundo que de antemão se acha superior, uma vez que, carregada dessas verdades e preconceitos (conceitos prévios, como a palavra indica), hierarquiza a relação com o outro, pretendendo levar a "civilização" ao selvagem, tema abordado no filme Brincando nos Campos do Senhor (1991, de Hector Babenco), que mostra o conflito entre catequizadores (que não conseguem se despir) e índios amazônicos (despidos), e radicaliza essa postura colocando em xeque a ideia de natureza humana universal.

No filme, uma missão evangelizadora composta por casais protestantes pretende converter uma perigosa tribo amazônica ao cristianismo. Dentre diversos problemas apresentados por esse choque cultural, duas cenas podem ser interpretadas sob o conceito de 
despir-se. O personagem Lewis Moon, um norte-americano de origem indígena, é contratado para exterminar a tribo, mas experimenta uma crise de identidade ao sobrevoar a aldeia dos índios, e após este momento de catarse decide se juntar aos indígenas. Ao embrenhar-se na mata, tira as próprias roupas e entra na tribo, aparentemente para se parecer com os índios, mas simbolicamente para se despir do que carregava de civilização e assim adentrar à experiência de forma aberta, sem defesas ou juízos prévios, enfim, nu. Noutra cena, a bela e pudica esposa do pastor protestante só consegue um contato mais aberto com o outro ao ser surpreendida por Moon quando está nua à beira do rio.

Contudo, uma postura dogmática não é por si suficiente para marcar o preconceito, é somente por meio de um horizonte de sentido prévio, a saber, o da tradição e do costume, que reduz a realidade a modelos, que indivíduos que partilham de uma cultura em comum, ao estarem no encontro com o diferente, se viram um para o outro, se cutucam, e sob olhar de julgamento procuram no comparsa a piscadela cínica que confirma: Como são selvagens!

A piscadela cínica seria a junção de posturas dogmáticas com o aceite do semelhante, o que definiria o ato preconceituoso. O cínico contemporâneo, diferentemente do cínico da Grécia antiga, que igualmente como o pirrônico buscava a ataraxia por meio de uma negação das convenções sociais, é o indivíduo que busca em seu semelhante, aquele com o qual partilha sua identidade, a afirmação de um preconceito que comungam, pois surgido de visões de mundo dogmáticas comuns a ambos.

Descobrimos o que é a felicidade - dizem os últimos homens e piscam os olhos. (NIETZSCHE em "Assim falava Zaratustra", p. 18)

Por medo da diferença, se protegem da alteridade buscando a própria identidade no semelhante e nas convenções sociais, nos dogmas. Portanto, estar vestido é conferir a si uma identidade, um escudo para defender-se, e estar nu é, de algum jeito, entregar-se à experiência com o outro, não temer a alteridade, não colocar um ideal de mundo no lugar do real.

Nesses termos, a gênese do preconceito parece ser mais facilmente encontrada nas posturas dogmáticas, e por mais que o ceticismo possa chegar a um relativismo cultural absoluto, ele parece ser mais capaz em lidar com a questão da alteridade, pois, se o ceticismo tem como princípio a suspensão do juízo, as posturas mais ligadas à tradição fazem exatamente o contrário, levantam juízos sobre comportamentos, em busca de uma suposta verdade ou da defesa de algo "natural". Um exemplo atual pode ser apresentado, o casal gay é mal visto pela 
ala conservadora da sociedade por ser não natural e não tradicional, de forma que os dogmas sociais, respaldados em juízos de verdade, dificultam uma abertura para a alteridade.

Para concluir nossa passagem pelos diferentes tipos de ceticismo, e retornar à Era Moderna, o racionalismo inaugurado por Descartes, uma engenhosa virada na forma de conhecermos o mundo, também se utiliza de um tipo provisório de ceticismo, embora também quisesse combatê-lo em nome de uma verdade mais efetiva. Sua dúvida metódica é não somente fundamental para seu método, como, por meio dela, foi possível um grande desenvolvimento do que conhecemos hoje como ciência. Contudo, Descartes esqueceu-se do corpo, ou melhor, o colocou numa posição menos importante.

Por sorte, o mesmo período nos brindou com um sábio do corpo, Bento de Espinosa, que ao negar o dualismo cartesiano propôs um racionalismo afetivo que aponta a importância do corpo e dos afetos. Segundo Espinosa, o que aumenta nossa capacidade de conhecer é a disposição do corpo em se compor ao ambiente por meio dos afetos. Algo que tanto o gimnosofista hindu quanto o índio brasileiro sabiam de antemão, pois viviam em sintonia, em conformidade com o ambiente.

Não é à toa que me utilizo do nu como título e fio condutor deste pequeno texto. Estar nu é uma característica do corpo que pretendo emprestar para a mente, mesmo porque não podemos dissociá-los. Somente nos despindo de dogmatismos é que podemos alcançar o outro, que podemos nos afetar bem, uma vez que não temos medo da alteridade, mas nos compomos com ela.

Concluo com um excerto, o trecho final do ensaio Sobre os Canibais, de Montaigne, e na tentativa de ressignificá-lo, um acréscimo ao final: "Tudo isso não é tão mau assim: mas ora! eles não usam calças". Ainda bem!

\section{Bibliografia}

BRITO, Rodrigo Pinto de. Notas sobre a Vida de Pirro. Prometeus, Ano 7, $\mathrm{n}^{\mathrm{o}}$ 16, JulhoDezembro/2014, p. 84-100.

DESCARTES, René. Discurso do Método. S. Paulo: Lafonte, 2017.

DIÔGENES LAÊRTIOS. Vidas e doutrinas dos filósofos ilustres. Brasília: Editora Universidade de Brasília, 2008.

GAZZINELli, G. G. A Vida Cética de Pirro. S. Paulo: Edições Loyola, 2009.

MARCONDES, Danilo. Montaigne, a descoberta do Novo Mundo e o Ceticismo Moderno. 
Kriterion, Belo Horizonte, no 126, Dezembro/2012, p. 421-433

MONTAIGNE, Michel de. Os ensaios: uma seleção. S. Paulo: Companhia das Letras, 2010.

NIETZSCHE, Friedrich. Assim falou Zaratustra. S. Paulo: Editora Schwarcz, 2011.

PLUTARCO. Alexandre, o grande. Rio de Janeiro: Ediouro, 2004.

SPINOZA, Benedictus de. Ética. Belo Horizonte: Autêntica, 2013.

\section{Internet:}

DODSWORTH Magnavita de Carvalho, Alexey. Gimnosofistas - as raizes orientais do ceticismo pirrônico. Disponível em <https://alexeydodsworth.net/2016/03/09/gimnosofistasas-raizes-orientais-do-ceticismo-pirronico/>. Acesso em 31 de maio de 2018.

GIMNOSOFISTAS. (n.d.) In: Wikipédia: a enciclopédia livre. Disponível em: $<$ https://pt.wikipedia.org/wiki/Gimnosofistas>. Acesso em 23 de maio de 2018.

GIMNOSOFISTI. (n.d.) In: Wikipédia: a enciclopédia livre. Disponível em: $<$ https://it.wikipedia.org/wiki/Gimnosofisti>. Acesso em 23 de maio de 2018.

GYMNOSOPHISTS. (n.d.) In: Wikipédia: a enciclopédia livre. Disponível em: $<$ https://en.wikipedia.org/wiki/Gymnosophists>. Acesso em 23 de maio de 2018.

\section{Filme:}

BRINCANDO nos Campos do Senhor. Direção de Hector Babenco. The Saul Zaentz Company, 1991, color (189 min). 